\title{
ANALISIS PERENCANAAN PENGELOLAAN KEUANGAN DESA SESUAI DENGAN PERATURAN MENTERI DALAM NEGERI NOMOR 113 TAHUN 2014 DI DESA KAUNERAN I KECAMATAN SONDER KABUPATEN MINAHASA
}

\author{
Mewvi I. Walukow ${ }^{1}$, Lintje Kalangi ${ }^{2}$, Sherly Pinatik ${ }^{3}$ \\ ${ }^{1,2,3}$ Fakultas Ekonomi dan Bisnis, Jurusan Akuntansi, Universitas Sam Ratulangi, Jl. Kampus Bahu, Manado, \\ 95115, Indonesia \\ E-mail : mewviwalukow@gmail.com
}

\begin{abstract}
Village financial management planning is the first step in the village financial management process. This planning stage is very important because in relation to village financial management, this stage of planning is the process by which the draft APBDesa will be developed. The purpose of this research is to know the financial planning in Kauneran I village, Sonder sub-district of Minahasa regency. This research uses qualitative analysis method. The results showed that at the planning stage of village financial management in the village of Kauneran I still not in accordance with Permendagri 113/2014. This is seen in the government regulations on APBDesa that should be evaluated by the local Bupati / Walikota is not implemented at all. In addition, the lack of participation from the community also becomes another fator of constraints in the planning stages of village finance management. This indicates that the financial management of villages in Kauneran I village has not implemented a participatory principle in accordance with Permendagri 113/201.
\end{abstract}

Keyword: Perencanaan Village's Financial Management, Permendagri No. 113/2014

\section{PENDAHULUAN}

Pedesaan adalah daerah permukiman penduduk yang sangat dipengaruhi oleh kondisi tanah, iklim, dan air sebagai syarat penting bagi terwujudnya pola kehidupan agraris penduduk di tempat itu, sedangkan perdesaan adalah daerah (kawasan) desa. Membangun desa berarti membangun sebagian besar penduduk Indonesia, hal ini mudah dimengerti karena lebih dari delapan puluh persen penduduk Indonesia tersebar di desa-desa seluruh Indonesia. Dinar Aji Atmaja (2016).

Pemerintah desa dalam mengurus semua urusan pemerintahan dan kepentingan masyarakat setempat, tentunya memerlukan pendapatan agar dapat mencapai tujuan dalam pembangunan dan kesejahteraan desa. salah satu sumber pendapatan desa yang dapat berfungsi sebagai sumber dalam kegiatan operasional desa dan untuk pemberdayaan masyarakat yang di atur pada pasal 72 ayat 1 huruf d Undang-Undang Nomor 6 Tahun 2014 tentang desa ialah Alokasi Dana Desa yang biasa disebut sebagai ADD, Alokasi Dana Desa yang merupakan bagian dari dana perimbangan yang di terima Kabupaten/ Kota. Alokasi Dana Desa sebagaimana di maksud diatas paling sedikit 10\% (sepuluh perseratus) dari dana perimbangan yang di terima Kabupaten/Kota dalam Anggaran Pendapatan Dan Belanja Daerah setelah dikurangi Dana Alokasi Umum atau DAU.

Objek penelitian ini adalah Desa Kauneran I yang merupakan desa pecahan dari desa Kauneran, desa Kauneran I merupakan salah satu desa dari 19 desa yang ada di Kecamatan Sonder Kabupaten Minahasa Provinsi Sulawesi Utara. Kecamatan Sonder sebelah utara berbatasan dengan Kota Tomohon, timur Kecamatan Romboken, selatan dengan Kecamatan Kawangkoan, dan barat dengan Kecamatan Tareran. Dalam pelaksanaan tugas dan kewajiban yang ada, setiap desa memerlukan sumber daya penunjang baik personil, dana dan juga peralatan penunjang lainnya, untuk itulah dalam Peraturan Pemerintah No. 72 tahun 2005 tentang Desa telah mengatur sumber pembiayaan bagi Desa dalam rangka memberikan 
pelayanan pada masyarakat antara lain dari sumber - sumber Pendapatan Asli Desa, adanya kewajiban bagi Pemerintah dari pusat sampai dengan Kabupaten/Kota untuk memberikan transfer dana bagi Desa, hibah ataupun donasi. Salah satu bentuk transfer dana dari pemerintah adalah Alokasi Dana Desa (ADD) yang telah ditetapkan sebesar 10\% dari dana perimbangan pemerintahan pusat dan daerah yang diterima masing-masing Pemerintah Kabupaten/Kota. Untuk itulah dalam rangka meningkatkan kesejahteraan masyarakat desa di Kecamatan Sonder, Pemerintah Kabupaten Minahasa memberikan Alokasi Dana Desa (ADD) dan Desa Kauneran I adalah salah satu desa dari 19 (Sembilan belas) desa yang ada Kecamatan Sonder yang menerima Alokasi Dana Desa.

Desa Kauneran I menerapkan Permendagri 113 tahun 2014 dalam mengelolah keuangan yang ada namun menurut temuan peneliti dilapangan dari hasil observasi dan wawancara awal dengan sekretaris desa Kauneran I, peran dan tanggung jawab yang diterima oleh desa belum diimbangi dengan Sumber Daya Manusia yang memadai dalam hal ini kualitas. Sebagai contoh dari hasil wawancara awal dengan sekretaris desa Kauneran I peneliti menemukan bahwa, sekretaris desa selaku koordinator pelaksana teknis pengelolaan keuangan desa belum melaksanakan tugasnya secara $100 \%$, contohnya pada proses perencanaan pengelolaan keuangan desa, ada tahap-tahap yang kurang diketahui oleh sekretaris desa dalam hal ini sekretaris desa tidak mengetahui dan kurang memperhatikan tahap evaluasi RKP desa tentang APBDesa yang harusnya dilakukan oleh Bupati. Padahal dalam hal ini dengan jelas ditulis dalam Permendagri 113 tahun 2014 tentang Pengelolaan Keuangan Desa sekretaris desa memegang peran yang sangat penting dalam pengelolaan keuangan desa, dari perencanaan, pelaksanaan, pelaporan serta pertanggungjawabannya, hal ini terjadi akibat kurangnya pengetahuan tentang Permendagri 113 tahun 2014 tentang Pengelolaan Keuangan Desa. Begitu pula dengan bendahara desa yang baru menjabat selama beberapa bulan dalam prakteknya bendahara desa masih harus banyak belajar dan bendahara desa juga belum mengetahui secara menyeluruh tentang keadaan desa dan tugasnya sebagai bendahara desa. Berdasarkan masalah yang telah diuraikan, maka tujuan dari penelitian ini adalah untuk mengetahuai perencanaan pengelolaan keuangan desa sudah sesuai dengan Permendagri no.113 tahun 2014 di desa Kauneran I Kecamatan Sonder Kabupaten Minahasa.

\section{TINJAUAN PUSTAKA}

\subsection{Teori Perencanaan}

Menurut Haryanto (2008:44) istilah perencanaan pembangunan, khususnya pembangunan ekonomi, sudah biasa terdengar dalam pembicaraan sehari-hari. Akan tetapi, perencanaan diartikan berbeda-beda dalam berbagai literature yang berbeda. Conyers \& hills (1994) mendefinisikan perencanaan sebagai "suatu proses yang berkesinambungan" yang mencakup " keputusan-keputusan atau pilihan-pilihan atas erbagai alternatif penggunanaan sumber daya untuk mencapai tujuan-tujuan tertentu pada masa yang akan datatang.

\subsection{Keuangan Desa}

Permendagri No. 113 Tahun 2014 menyatakan bahwa, Keuangan Desa adalah semua hak dan kewajiban desa yang dapat dinilai dengan uang serta segala sesuatu berupa uang dan barang yang berhubungan dengan pelaksanaan hak dan kewajiban desa. Hak dan kewajiban dapat menimbulkan pendapatan, belanja, pembiayaan dan pengelolaan. Dalam pasalnya yang kedua, Asas Pengelolaan Keuangan Desa adalah sebagai berikut:

1. Keuangan desa dikelola berdasarkan asas-asas transparan, akuntabel, partisipatif serta dilakukan dengan tertip dan disiplin.

2. Pengelolaan keuangan desa sebagaimana dimaksud pada ayat (1), dikelola dalam masa 1 (satu) tahun anggaran yakni mulai tanggal 1 Januari sampai dengan tanggal 31 Desember

a. Transparan artinya terbuka, tidak ada yang ditutupi

b. Akuntabel artinya dapat dipertanggung jawabkan 
c. Partisipatif artinya mengutamakan keterlibatan masyarakat

d. Tertib dan disiplin anggaran artinya konsisten, tepat waktu, tepat jumlah dan taat asas.

Menurut UU No. 6 tahun 2014 pasal 71, Pendapatan Desa bersumber dari:

1. Pendapatan asli Desa terdiri atas hasil usaha, hasil asset, swadaya dan partisipasi, gotong royong, dan lain-lain pendapatan asli Desa.

2. Alokasi Anggaran Pendapatan Dan Belanja Negara.

3. Bagian dari hasil pajak daerah dan retribusi daerah Kabupaten/Kota.

4. Alokasi dana Desa yang merupakan bagian dari dana perimbangan yang di terima Kabupaten/Kota.

5. Bantuan keuangan dari Anggaran pendapatan dan Belanja Provinsi dan Anggaran Pendapatan dan Belanja Daerah Kabupaten/Kota.

6. Hibah dan sumbangan yang tidak mengikat dari pihak ketiga, dan

7. Lain-lain pendapatan Desa yang sah.

Alokasi anggaran yang dimaksud diatas bersumber dari belanja pusat dengan mengefektifkan program yang berbasis desa secara merata dan berkeadilan. Bagian hasil pajak daerah dan retribusi daerah Kabupaten/Kota paling sedikit 10\% (sepuluh perseratus) dari pajak dan retribusi daerah. Alokasi dana desa paling sedikit 10\% (sepuluh perseratus) dari pajak dan retribusi daerah. ADD mengandung makna bahwa desa memiliki kewenangan untuk mengatur dan mengurus rumah tangganya sendiri dengan kewenangan asli maupun yang diberikan,yang menyangkut peranan pemerintah desa sebagai penyelenggara pelayanan publik didesa dan sebagai pendamping dalam proses perencanaan dan pelaksanaan pembangunan daerah yang melibatkan masyarakat di tingkat desa. Muntanah dan Murdijaningsih (2014:2).

Menurut Permendagri No. 113 Tahun 2014, Pengelolaan Keuangan Desa adalah keseluruhan kegiatan yang meliputi perencanaan, pelaksanaan, penatausahaan, pelaporan, dan pertanggungjawaban keuangan desa. Kekuasaan Pengelolaan Keuangan Desa antara lain:

\subsection{Perencanaan Pengelolaan Keuangan Desa}

\subsubsection{Penyusunan Rencana Pembangunan Jangka Menengah Desa dan Rencana} Kerja Pemerintah Desa

Proses penyusunan perencanaan dimulai dengan tahap penyusunan RPJMDes dan RKPdes. Pemerintah desa menyusun perencanaan pembangunan desa sesuai dengan kewenangannya dengan mengacu pada perencanaan pembangunan Kabupaten/Kota. Perencanaan Pembangunan Desa disusun secara berjangka meliputi:

a. Rencana Pembangunan Jangka Menengah Desa untuk jangka waktu 6 (enam) tahun. RPJM-Des adalah program pemerintah yang mengatur tentang rancangan dan penyusunan pembangunan desa yang disusun oleh Kepala Desa terpilih secepatnya untuk mewujudkan apa yang telah disampaikan pada janji kampanye pemilihan Kepala Desa dan menjabarkan visi dan misi. Irwan Muhadi (2013:8).

b. Rencana Pembangunan Tahunan Desa atau yang disebut Rencana Kerja Pemerintah Desa, merupakan penjabaran dari rencana Pembangunan jangka Menengah Desa untuk jangka waktu 1 (satu) tahun.

\subsubsection{Penetapan Pelaksana Teknis Pengelolaan Keuangan Desa}

Menurut Permendagri No. 113 Tahun 2014 Bab III Pasalnya yang 3 menyatakan bahwa:

(2) Kepala Desa adalah pemegang kekuasaan pengelolaan keuangan desa dan mewakili Pemerintah Desa dalam kepemilikan kekayaan milik desa yang dipisahkan. Kepala Desa mempunyai kewenangan:

a. Menetapkan kebijakan tentang pelaksanaan APBDesa

b. Menetapkan PTPKD

c. Menetapkan petugas yang melakukan pemungutan penerimaan desa 
d. Menyetujui pengeluaran atas kegiatan yang ditetapkan dalam APBDesa dan

e. Melakukan tindakan yang mengakibatkan pengeluaran atas beban APBDesa

(3) Kepala desa dalam melaksanakan pengelolaan keuangan desa dibantu oleh PTPKD

Pasal 4

PTPKD sebagaimana dimaksud dalam pasal 3 ayat (3) berasal dari unsur perangkat desa, Terdiri dari:

a. Sekretaris Desa,

b. Kepala seksi, dan

c. Bendahara Desa

\subsubsection{Penyusunan Rancangan Peraturan Desa}

Menurut Permendagri Nomor 113 Tahun 2014 Bab V menyatakan bahwa :

Pasal 20

(1) Sekretaris desa menyusun Rancangan peraturan Desa tentang APBDesa berdasarkan RKPDesa tahun berkenan.

(2) Sekretaris desa menyampaikan rancangan peraturan desa tentang APBDesa kepada Kepala Desa.

(3) Rancangan Peraturan Desa tentang APBDesa sebagaimana dimaksud pada ayat (2) di sampaikan oleh Kepala Desa kepada Badan Permusyawaratan Desa untuk dibahas dan disepakati bersama.

(4) Rancangan Peraturan Desa tentang APBDesa disepakati bersama sebagaimana dimaksud dalam ayat (3) paling lambat bulan oktober tahun berjalan.

\subsubsection{Evaluasi Rancangan Peraturan Desa}

\section{Pasal 21}

(1) Rancangan Peraturan Desa tentang APBDesa yang telah disepakati bersama sebagaimana dimaksud dalam pasal 20 ayat (3) disampaikan oleh Kepala Desa kepada Bupati/Walikota melalui camat atau sebutan lain paling lambat 3 (tiga) hari sejak disepakati untuk dievaluasi.

(2) Bupati/Walikota menetapkan hasil evaluasi Rancangan APBDesa sebagaimana dimaksud pada ayat (1) paling lama 20 (dua puluh) hari kerja sejak diterimanya Rancangan Peratuan Desa tentang APBDesa.

(3) Dalam hal ini Bupati/Walikota tidak memberikan hasil evaluasi dalam batas waktu sebagaimana dimaksud pada ayat (2) Peraturan Desa tersebut berlaku dengan sendirinya.

(4) Dalam hal ini Bupati/Walikota menyatakan hasil evaluasi Rancangan Desa Tentang APBDesa tidak sesuai dengan kepentingan umum dan peraturan perundang-undangan yang lebih tinggi, Kepala Desa melakukan penyempurnaan paling lama 7 (tujuh) hari kerja terhitung sejak diterimanya hasil evaluasi.

\section{Pasal 22}

(1) Apabila hasil evaluasi tidak ditindaklanjuti oleh Kepala Desa dan kepala desa tetap menetapkan Rancangan peraturan Desa tentang APBDesa menjadi Peraturan Desa, Bupati/Walikota membatalkan Peraturan Desa dengan Keputusan Bupati/Walikota.

(2) Pembatalan Peraturan Desa sebagaimana dimaksud pada ayat (1) sekaligus menyatakan berlakunya pagu APBDesa tahun anggaran sebelumnya.

(3) Dalam hal pembatalan sebagaimana dimaksud pada ayat (2) Kepala Desa hanya dapat melakukan pengeluaran terhadap operasional penyelenggaraan Pemerintah Desa.

(4) Kepala Desa memberhentikan pelaksanaan Peraturan Desa paling lama 7 (tujuh) hari kerja setelah pembatalan dan selanjutnya Kepala Desa bersama BPD mencabut peraturan desa yang dimaksud. 


\subsection{Penelitian Terdahulu}

Penelitian terdahulu ini menjadi salah satu acuan peneliti dalam melakukan penelitian sehingga peneliti dapat memperkaya teori yang dapat digunakan dalam mengkaji penelitian yang dilakukan peneliti yaitu

\section{METODE PENELITIAN}

\subsection{Jenis dan sumber data}

Metode penelitian yang digunakan dalam penelitian ini adalah penelitian kualitatif. Menurut Sugiyono (2016: 1), Metode penelitian kualitatif digunakan untuk mendapatkan data yang mendalam, suatu data yang mengandung makna, makna adalah data yang sebenarnya, data yang pasti yang merupakan suatu nilai dibalik data yang tampak.

\subsection{Metode analisis}

Metode analisis data yang digunakan dalam penelitian ini adalah metode deskriptif. Tujuan dari penelitian deskriptif ini adalah untuk membuat deskipsi, gambaran atau lukisan secara sistematis, faktual dan akurat mengenai fakta-fakta, sifat-sifat serta hubungan antar fenomena yang diselidiki.

\section{HASIL PENELITIAN DAN PEMBAHASAN}

\subsection{Hasil Penelitian}

\section{Perencanaan Pengelolaan Keuangan Desa}

Dari hasil penelitian perencanaan pengelolaan keuangan desa terdiri dari:

1. Disusunnya RPJMDes dan RKPDes

2. Penetapan Pelaksana Teknis Pengelolaan Keuangan Desa

3. Sekretaris desa menyusun rancangan peraturan desa tentang APBDesa berdasarkan RKPDesa tahun berkenan

4. Setelah di sepakati Bupati/Walikota melalui camat atau sebutan lain paling lambat 3 (tiga) hari sejak disepakati untuk di evaluasi.

\subsection{Rencana Pembangunan Jangka Menengah Desa (RPJMDES) Dan Rencana Kerja Pemerintah Desa (RKPDES)}

A. Rencana Pembangunan Jangka Menengah Desa (RPJMDES)

Dari hasil wawancara dengan salah satu meweteng yang ada didesa Kauneran I RPJMDES disusun dengan cara mengadakan pertemuan/ musyawarah jaga yang dihadiri oleh waki-wakil dari masyarakat yang ada di jaga itu masing-masing, dari hasil dokumentasi musyawarah yang antar jaga dilaksanakan pada:

\begin{tabular}{|c|c|c|c|}
\hline No. & JAGA & WAKTU PELAKSANAAN & TEMPAT \\
\hline 1 & 1 & 21 Desember 2011 & Kel. M. Sumakul Komaling \\
\hline 2 & 2 & 22 Desember 2011 & Kel. R. Menajang Ruus \\
\hline 3 & 3 & 23 Desember 2011 & Kel. J Ombeng Walangitan \\
\hline 4 & 4 & 24 Desember 2011 & Kel. R. Sendow Assa \\
\hline
\end{tabular}

Dari hasil dokumentasi dari dokumen RPJMDes desa Kauneran I, Maksud dan Tujuan Disusunyan Rencana Pembangunan Jangka Menengah Desa (RPJMDes)

1. Maksud disusunnya Rencana Pembangunan Jangka Menengah Desa (RPJMDes) adalah sebagai pedoman bagi setiap perangkat desa dalam menyusun sasaran, program dan kegiatan pembangunan desa.

2. Tujuan disusunnya Rencana Pembangunan Jangka Menengah Desa (RPJMDes) adalah untuk meningkatkan pelaksanaan pemerintahan dan pembangunan serta pelayanan kepada masyarakat yang lebih berdaya guna, serta lebih untuk 
memantapkan pelaksanaan akunabilitas kinerja pemerintah desa sebagai wujud pertanggungjawaban dalam mencapai visi ,misi dan tujuan pemerintah desa.

Arah Kebijakan Keuangan Desa sesuai dengan RPJMDES

1. Arah Kebijakan Pengelolaan Pendapatan Desa

Dalam rangka meningkatkan kemandiriam desa maka arah kebijakan berkaitan dengan penerimaan adalah sebagai berikut:

a. Meningkatkan Pendapatan dari hasil usaha desa dengan cara memperdayakan Badan Usaha Milik Desa melalui potensi desa yang ada.

b. Mengoptimalkan pendapatan dari pengelolaan potense desa yang ada.

c. Memperbesar partisipasi masyarakat.

d. Mengintensifkan pungutan administrasi kator desa

e. Menggalang pendanaan dari pihak ketiga

2. Arah Kebijakan Pengelolaan Belanja Desa

Berdasarkan masalah yang dihadapi Desa serta program prioritas tahun 2011- 2017 maka arah kebijakan belanja desa adalah sebagai berikut:

a. Efiensi anggaran pada belanja rutin seperti:

Pos belanja pegawai, perjalanan dinas, konsumsi, dan pengeluaran tak terduga.

b. Memperbesar alokasi belanja fisik dan belanja nonfisik atau belanja bantuan SOSIAL dalam mempercepat pengurangan angka kemiskinan seperti:

Pos belanja pembangunan dalam desa dan pelatihan masyarakat dan kepemerintahan desa.

3. Rencana Kerja Pemerintah Desa (RKP Desa)

Berdasarkan hasil wawancara dan dokumentasi Rencana Keja Pemerintah Desa yang ada didesa Kauneran I untik tahun anggaran 2017 disusun dengan cara mengadakan Musrembang yang telah dilaksanakan pada tanggal 23 januari 2016 dengan materi atau topic yaitu: review usulan RPJMDES dan penetapan RKPDes untuk tahun 2017 . Berdasarkan hasil dokumentasi tujuan dan manfaat Penyusunan Rencana Kerja Pemerintah Desa (RKPDes) adalah sebagai berikut:

1. Tujuan penyusunan Rencana Kerja Pemerintah Desa (RKPDes)

a. agar desa memiliki dokumen perencanaan pembangunan tahunan yang berkekuatan hukum tetap

b. sebagai dasar/ pedoman kegiatan pelaksanaan pembangunan didesa

c. sebagai dasar penyusunan peraturan desa tentang Anggaran Pendapatan dan Belanja Desa (APBDes)

2. Manfaat penyusunan Rencana Kerja Pemerintah Desa (RKPDes)

a. Lebih menjamin kesinambungan pembangunan ditingkat desa

b. Sebagai pedoman dan acuan pembangunan desa

c. Pemberi arah kegiatan pembangunan tahunan didesa

d. Menampungan aspirasi yang sesuai kebutuhan masyarakat dan dipadukan dengan program pembanunan supra desa

e. Dapat mendorong partisipasi dan swadaya dari masyarakat

A. Arah Kebijakan Keuangan Desa Berdasarkan RKPDESA

Adapun APBDesa terdiri atas:

1. Pendapatan Desa

Pendapatan desa meliputi semua penerimaan uang melalui rekening desa yang merupakan hak desa dalam 1 (satu) tahun anggaran yang tidak perlu dibayar kembali oleh desa. Pendapatan desa terdiri atas kelompok:
a. Pendapatan Asli Desa (PADesa)
b. Transfer
c. Pendapatan lain-lain 
Pendapatan Asli Desa (PAD) terdiri atas jenis:

a. Hasil usaha

b. Hasil asset

c. Swadaya, partisipasi dan gotong-royong

d. Lain-lain pendapatan asli desa

Hasil usaha desa antara lain hasil Bumdes, tanah kas desa. hasil asset antara lain jaringan irigasi. Swadaya, partisipasi dan gotong-royong adalah membangun dengan kekuatan sendiri yang melibatkan peran serta masyarakat berupa tenaga, barang yang dinilai dengan uang. Lain-lain pendapatan asli desa antara lain hasil pungutan desa.

Kelompok transfer terdiri atas jenis:

a. Dana desa

b. Bagian dari Hasil Pajak Daerah Kabupaten/Kota dan Retribusi Daerah

c. Alokasi Dana Desa (ADD)

d. Bantuan Keuangan dari APBD Provinsi

e. Bantuan Keuangan APBD Kabupaten/Kota

Bantuan keuangan dari APBD Provinsi dan Kabupaten/Kota dapat bersifat umum dan khusus. Bantuan keuangan bersifat khusus di kelola dalam APBDesa tetapi tidak diterapkan dalam ketentuan penggunaan paling sedikit $70 \%$ (tujuh puluh perseratus) dan paling banyak $30 \%$ (tiga puluh perseratus).

Kelompok pendapatan lain-lain terdiri atas jenis:

a. Hibah dan Sumbangan dari Pihak ketiga yang tidak mengikat

b. Lain-lain pendapatan desa yang sah

Hibah dan Sumbangan dari Pihak ketiga yang tidak mengikat adalah pemberian berupa uang dari pihak ke tiga dan lain-lain pendapatan desa yang sah, antara lain pendapatan sebagai hasil kerjasama dengan pihak ketiga dan bantuan perusahaan yang berlokasi didesa.

Adapun asumsi pendapatan desa tahun anggaran 2016 sebesar Rp. 897.852.000,- (delapan ratus Sembilan puluh tujuh juta delapan ratus lima puluh dua ribu rupiah).

2. Belanja Desa

Belanja desa, meliputi semua pengeluaran dari rekening desa yang merupakan kewajiban desa dalam 1 (satu) tahun anggaran yang tidak akan diperoleh pembayarannya kembali oleh desa. Belanja desa dipergunakan dalam rangka mendanai penyelenggaraan kewenangan desa.

Klasifikasi Belanja Desa terdiri atas kelompok:

a. Penyelenggaraan Pemerintah Desa

b. Pelaksanaan Pembangunan Desa

c. Pembinaan Kemasyarakatan Desa

d. Pemberdayaan Masyarakat Desa

e. Belanja Tak terduga

Pemerintah desa dapat membentuk dana cadangan untuk mendanai kegiatan yang penyediaan dananya tidak dapat sekaligus/sepenunya di bebankan dalam satu tahun anggaran. Pembentukan dana cadangan di tetapkan dengan peraturan desa. peraturan desa paling sedikit memuat:

1. Penetapan tujuan pembentukan dana cadangan

2. Program dan kegiatan yang dibiayai dari dana cadangan

3. Besaran dan rincian tahunan dana cadangan yang harus dianggarkan

4. Sumber dana cadangan

5. Tahun anggaran pelaksanaan dana cadangan

Pembentukan dana cadangan dapat bersumber dari penyisihan atas penerimaan desa, kecuali dari penerimaan yang penggunaannya telah ditentukan secara khusus berdasarkan 
peraturan perundang-undangan. Pembentukan dana cadangan ditempatkan pada rekening tersendiri. Penganggaran dana cadangan tidak melebihi tahun akhir masa jabatan kepala desa.

\subsubsection{Penetapan Pelaksana Teknis Pengelolaan Keuangan Desa}

Dari hasil wawancara dengan sekretaris desa Kauneran I Pelaksana Teknis Keuangan Desa ditetapkan atau ditunjuk langsung oleh Kepala Desa Kauneran I sebagai pemegang kekuasaan pengelolaan keuangan desa. Dan didesa Kauneran I yang menjadi PTPKD adalah sebagai berikut:

a. Sekretaris Desa selaku Koordinator Pelaksana Teknis Pengeloaaan Keuangan Desa

b. Kepala Seksi bertindak sebagai pelaksana kegiatan

c. Bendahara selaku staf pada urusan keuangan

\subsubsection{Penyusunan Rancangan Peraturan Desa}

Dari hasil wawancara dengan sekretaris desa Kauneran I, tugas dari sekretaris desa selaku koordinator PTPKD dalam tahap perencanaan adalah menyusun peraturan desa yang berisi tentang APBDesa, Anggaran Pendapatan dan Belanja Desa disusun berdasarkan RKPDesa yang telah disusun sebelumnya melalui musrembangdes dengan para perangkat desa, BPD, serta masyarakat desa Kauneran I. Didesa Kauneran I Peraturan Desa tentang APBDesa dibuat dalam bentuk proposal Pengajuan Dana tahun anggaran 2016 (terlampir), setelah disusunnya rancangan peraturan desa tersebut selanjutnya diperiksa oleh Hukum Tua Desa Kauneran I dan dibahas dengan anggota BDP apakah rancangan peraturan desa tersebut sudah benar dan sesuai dengan yang telah dibicarakan sebelumnya.

Sekretaris desa juga bertanggung jawab penuh dalam proses pengendalian dan pelaporan pelaksana APBDesa, sekretaris desa mengatakan bahwa "jika kepala seksi sebagai pelaksana kegiatan pembangunan ingin mengambil tindakan, belanja alat atau perlengkapan harus terlebih dahulu diberitahukan kepada sekretaris desa sebagai koordinator PTPKP".

\subsubsection{Evaluasi Rancangan APBDesa Di Desa Kauneran I}

Tahap evaluasi rancangan peraturan desa tentang APBDesa Kauneran I tidak dilakukan. Menurut hasil wawancara dengan sekretaris desa tahap ini tidak dilakukan dan bahkan sekretaris desa Kauneran I tidak tahu-menau tentang tahap ini. Rancangan peraturan desa yang telah dibuat diserahkan kepada Hukum Tua dan langsung di serahkan kepada camat tanpa ada evaluasi. Rancangan tersebut langsung diproses sebagaimana yang telah disusun sebelumnya.

\subsubsection{Faktor Penghambat Perencanaan Pengelolaan keuangan Desa Di Desa Kauneran I}

Perencanaan pengelolaan keuang desa di desa Kauneran I masih belum maksimal, hal ini terlihat dari tidak adanya evaluasi terhadap rancangan peraturan desa tentang APBDesa. Dari hasil wawancara dengan beberapa narasumber serta dari hasil observasi di desa Kauneran I, ditemukan beberapa factor penghambat perencanaan pengelolaan keuangan desa diantaranya: kurangnya pengetahuan tentang Permendagri no. 113 tahun 2014 tentang pengelolaan keuangan desa, kurangnya partisipasi masyarakat dalam proses perencanaan pengelolaan keuangan desa, kurangnya pengawasan masyarakat dalam tahap perencanaan pengeloaan keuangan desa dan terbatasnya kemampuan dari pemerintah desa

\section{KESIMPULAN DAN SARAN}

\subsection{Kesimpulan}

Berdasarkan hasil analisis data yang telah dilakukan maka dapat ditarik kesimpulan bahwa

1. Adanya ketidaksesuaian perencanaan pengelolaan keuangan desa yang ada didesa Kauneran I dengan perencanaan pengelolaan keuangan desa yang ada dalam Permendagri 113 tahun 2014 , tingkat kesesuaian antara perencanaan pengelolaan 
keuangan desa yang ada di desa Kauneran I dengan Peraturan Menteri Dalam Negeri Nomor 113 Tahun 2014 baru sekitar 80\%. Ketidaksesuian ini ada di tahap akhir yaitu tahap evaluasi, dimana peraturan desa tentang rancangan Anggaran Pendapatan dan Belanja Desa yang harusnya di evaluasi paling lama 20 (dua puluh) hari kerja sejak diterimanya rancangan peraturan desa tersebut oleh Bupati/Walikota dan harus ditindaklanjuti oleh Kepala Desa atau biasa disebut dengan HukumTua Desa Kauneran I sama sekali tidak dilakukan. Hal ini terjadi dikarenakan kurangnya pengetahuan dan bimbingan langsung tentang Permendagri nomor 113 tahun 2014 di Desa Kauneran I.

2. Faktor penghambat lainnya dalam tahap perencanaan pengelolaan keuangan desa di desa Kauneran I yaitu kurangnya kesadaran masyararakat untuk berperan aktif dalam tahap perencanaan pembangunan desa dan kurangnya pengawasan yang dilakukan masyarakat dalam tahap penyusunan anggaran pembangunan yang ada di desa Kauneran I. Dengan adanya ketidaksesuaian perencanaan keuangan desa didesa Kauneran I dengan perencanaan pengelolaan keuangan desa menurut Permendagri No. 113 tahun 2014 dan kurangnya partisipasi dari masyarakat menunjukkan bahwa Desa Kauneran I tidak secara $100 \%$ taat pada azas pengelolaan keuangan desa, dalam ha ini ialah asas partisipatif.

\subsection{Saran}

Berdasarkan hasil penelitian mengenai Analisis Perencanaan pengelolaan keuangan Desa Sesuai Dengan Peraturan Menteri Dalam Negeri Nomor 113 Tahun 2014 Di Desa Kauneran I Kecamatan Sonder Kabupaten Minahasa, makapenulis dapat memberikan saran sebagai berikut:

1. Harus Diadakan sosilisasi, pelatihan dan pembinaan secara langsung dan menyeluruh tentang Peraturan Menteri Dalam Negeri Nomor 113 Tahun 2014 kepada pemerintah desa, BPD, lembaga desa, agar nantinya setiap keuangan desa yang ada bisa dikelola berdasarkan dengan azas-azas transparan, akuntabel, partisipatif serta dilakukan dengan tertib dan disiplin anggaran. Dan didesa Kauneran I Kecamatan Sonder juga harus diadakan bimbingan secara terus-menerus tentang tugas setiap anggota perangkat desa yang ada, agar setiap perangkat desa dapat bekerja sesuai dengan fungsi dan tugasnya masing-masing, hal ini harus dilakukan untuk mencegah adanya kecurangan atau hal-hal yang tidak diinginkan.

2. Pemerintah harus melakukan sosialisasi dan pelatihan tentang pentingnya peran dan tugas dari masyarakat dalam membangun desa, termasuk didalamnya adalah dalam proses penyusunan perencanaan keuangan desa, hal ini berguna untuk mencegahnya kesalahpahaman dan pertentangan antara masyarakat dengan pemerintah desa yang ada.

\section{DAFTAR PUSTAKA}

Atmaja, Dinar. 2016. Analisis Pengelolaan Keuangan Dan Kekayaan Desa (studi kasus di Desa Plesungan Kecamatan Gondangrejo kabupaten karanganyar) . E-jurnal katalogis. ISSN 2302-2019. Volume 3. Univerisitas Muhammadiyah Surakarta

Dadang. 2006. Keuangan Publik: Pendanaan Pusat Dan Daerah. Edisi Pertama. Cetakan Pertama. P.T. Artifa Duta Prakarsa.

Dewanti, Elsa. 2015. Analisis Perencanaan Pengelolaan Keuangan Desa Di Desa Boreng (Studi Kasus Pada Desa Boreng kecamatan Lumajang Kabupaten Lumakang). Jurnal Unej. Digital Repository.Universitas Jember.

Haryanto. 2008. Perencanaan Dan Penganggaran Daerah Pendekatan Kinerja. Edisi

Pertama. Cetakan Pertama. Badan Penerbit Universitas Dipenogoro. Semarang.

Ibrahim. 2015. Metodologi Penelitian Kualitatif. Alfabeta. Bandung. 
Ismail Muhammad, Widagdo Ari Kuncara, Widodo Agus. 2015. Sistem Akuntansi Pengelolaan Keuangan Desa. Jurnal Ekonomi Dan Bisnis. ISSN 2979-6471. Volume XIX No. 2. Fakultas Ekonomi Dan Bisnis. Universitas Sebelas Maret. Surakarta.

Iqsan. 2012. Transparasi Pemerintah Desa Dalam Penyusunan Anggaran Pendapatan Dan Belanja Desa (APBDES) Di Desa Long Nak Kecamatan Muara Ancalong Kabupaten Kutai Timur. E-jurnal ilmu pemerintahan.2016, 4(1): 230-240. ISSN 2477- 2631. Universitas Mulawarman. Samarinda.

Kazimoto, Paluku. 2013. Analysis of village financial management Challeges in Arumeru District Tanzania. International Jurnal of Researcg In Social Science. Vol . 3(2) October, 2013. ISSN 2307-227x. University Of Arusha. United Republic Of Tanzania.

Lestari Ni Nyoman Sri Ayu, Bagia I Wayan, Jana Gede Putu Agus Susila. 2015. Pengaruh Anggaran Pendapatan belanja Negara (APBN) Terhadap Belanja Langsung Pada Pemerintah Daerah Kabupaten/Kota. e-journal Bisma Universitas Pendidikan Ganesha. Volume 3 tahun 2015. Universitas Pendidikan Ganhesa. Singaraja.

Mardiasmo. 2013. Akuntansi Sektor Publik. Andi. Yogyakarta.

Mardiasmo. 2014. Akuntansi Keuangan Dasar. Edisi Tiga. Cetakan Keempat. BPFEYOGYAKARTA.

Melis. 2016, Analisis Partisipasi Masyarakat Dalam Pembangunan Desa (Studi Di Desa Wawolesea Kecamatan Lasolo Kabupaten Kanowe Utara). Jurnal Ekonomi (JE) Vol. 1(1), April 2016. E-ISSN: 2503-1937. Page: 99-105. Universitas Halu Oleo Kendari.

Peraturan Menteri Dalam Negeri Nomor 113 Tahun 2014 Tentang Pengelolaan Keuangan Desa.

Peraturan Menteri Dalam Negeri Nomor 114 Tahun 2014 Tentang Pedoman Pembangunan Desa.

Peraturan Pemerintah Republik Indonesia Nomor 71 Tahun 2010 Tentang Standar Akuntansi Pemerintahan. 